\title{
Psychological Impact of COVID 19 on the Amount of Perceived Stress among College Students Studying across Various Streams in India during the Period of Lockdown
}

\author{
Parthiban Bijulakshmi ${ }^{1}$, Vikhram Ramasubramanian², Mathumathi³ , Gopi Rajendhiran', C Ramasubramanian ${ }^{5}$ \\ ${ }^{1}$ Department of Psychology, Ahana Hospitals LLP, Gandhi Nagar, Madurai, Tamilnadu, India. ${ }^{2}$ Department of \\ Psychiatry, M.S. Chellamuthu Trust and Research Foundation, K.K. Nagar, Madurai, Tamil Nadu, India \& \\ Psychiatrist, Ahana Hospitals LLP, Gandhi Nagar, Madurai, Tamilnadu, India. ${ }^{3}$ Department of Psychiatry, Ahana \\ hospitals LLP, Gandhi Nagar, Madurai, Tamilnadu, India. ${ }^{4}$ Department of Psychiatry, Ahana Hospitals, Madurai, \\ Tamilnadu, India. ${ }^{5}$ Department of Psychiatry, Ahana Hospitals LLP, Gandhi Nagar, Madurai, Tamilnadu, India \& \\ Founder, M.S. Chellamuthu Trust and Research Foundation, K.K. Nagar, Madurai, Tamilnadu, India.
}

\section{ABSTRACT}

\section{BACKGROUND}

Humans have evolved and adapted as a social being and it has ensured the survival of all. The novel corona virus, COVID 19 has impacted the psychosocial functioning of billions of people around the world. The various impacts it might have on different categories of people over a period of time is one of the main concerns of the World Health Organisation. College students are vulnerable and are more prone to psychological problems due to the prolonged stress experienced by them during this period of uncertainty and social isolation. We wanted to analyse the level of perceived stress among college students in India and the impact of this sudden break in studies and social distancing has on them. We also wanted to study the number of mental setbacks the college students experience because of their financial situation and their future job prospects during this lockdown.

\section{METHODS}

An online survey was conducted among the college students in India. A total of 775 responses were analysed for the level of perceived stress using the perceived stress scale. The psychological impact caused by the lockdown was analysed through statements regarding the amount of worry they felt across various aspects of their life such as economic stability, missing friends during lockdown, use of mobile phone for connecting with people, continuation of education and impact of Covid 19 on future job prospects.

\section{RESULTS}

College students were experiencing significant amount of stress as measured by the perceived stress (PS) scale with $11.5 \%$ experiencing high stress and $81.2 \%$ students experiencing moderate amount of stress. The perceived stress was found to be significantly associated with worry regarding education, job prospects being affected by the Covid 19 situation and the reduction of time spent with their peers.

\section{CONCLUSIONS}

College students are experiencing moderate to high level of stress in the context of the pandemic situation and preventive and protective measures have to be taken by the college administration to address these issues. More targeted assessments needs to be done in colleges to assess the mental health of its student population and protective measures like counselling services should be made to vulnerable students as they try to handle the stress associated with the current pandemic situation.

\section{KEY WORDS}

COVID 19, Perceived Stress, College Students, Social Isolation, Worry Regarding job Prospects, Break in Education

\author{
Corresponding Author: \\ Ms. P. Bijulakshmi. \\ 6-4-31, First avenue, \\ Viswanathapuram, Madurai-625014, \\ Tamilnadu, India. \\ E-mail: bijupathiban26@gmail.com
}

DOI: $10.14260 /$ jemds/2020/632

How to Cite This Article:

Bijulakshmi P, Ramasubramanian V, Mathumathi, et al. Psychological impact of COVID 19 on the amount of perceived stress among college students studying across various streams in India during the period of lockdown. J Evolution Med Dent Sci 2020;9(39):2889-2893,

10.14260/jemds/2020/632

DOI:

Submission 19-06-2020,

Peer Review 21-08-2020

Acceptance 27-08-2020,

Published 28-09-2020.

Copyright (C) 2020 Parthiban Bijulakshmi, et al. This is an open access article distributed under Creative Commons Attribution License [Attribution 4.0 International (CC BY 4.0)] 


\section{BACKGROUND}

The World Health Organisation ${ }^{1}$ declared the new Corona virus outbreak as a pandemic in March 2020. The primary strategy adopted by the world countries to curb the spread of virus is by imposing lockdown. India went into lockdown from March 23, 2020 in an effort to contain the spread of the virus. It has been a period of uncertainty and stress for all stake holders fighting to contain the spread of the virus. India being the country with the world's largest youth population is known for its vibrant social environment and its importance in maintaining the family structure and society at large. While medical professionals are fighting to contain and manage the corona virus, psychiatrists and psychologists are worried about the psychological impact this crisis has on people now and its possible impact on people in the future. The most effective way to contain the spread of Corona virus-social distancing has a negative impact on the psycho-social wellbeing of people.

The psychological consequences of social distancing, as affected by the lockdown is the feeling of isolation and uncertainty. ${ }^{2}$ Isolation and uncertainty can lead to persisting feelings of stress, resulting in many conditions like anxiety, post-traumatic stress disorder, depression and panic disorder. $^{2}$ The World Health Organization has issued guidelines on the psychosocial impact, this crisis might have on people of different groups, ${ }^{1}$ focusing mainly on children, caregivers of children, elderly people and on the long term impact of increase in people suffering from anxiety disorders, depression, addiction and increase in problems such as domestic violence and sexual offences. It has clearly outlined the need to have preventive and protective measures set up to deal with these issues.

College students suffer from mental health issues and a study based on WHO data has shown that ${ }^{3}$ nearly one fifth of the young adults had a diagnosable mental health problem over a 12 month period. Young adults especially college students have been largely excluded from most of the studies especially in the context of pandemics. Studies that were conducted early during similar pandemics have largely concentrated on the infection rate and mortality rate and its effect on the mental health of people during and after the pandemic. There are numerous studies ${ }^{4,5}$ that study the fear of infections, the periods of social distancing and quarantine ${ }^{6}$ and the impact it has on people and front line workers who are fighting the spread of the disease that includes medical and paramedical professionals.

Students enter college at about the age of $17 \mathrm{yrs}$ and are expected to acquire skills and education that will prepare them to enter the work force in a span of $3-6$ yrs. The cultural system in India with its diversity, expects the young adults to conform within their cultural boundaries while working to excel in their productive skills and secure jobs at the earliest. There is a constant pressure from the family, the staff, peers and stiff competition in the employment sector which results in a lot of stress among the students in colleges, ${ }^{7,8}$ resulting in various psychological and physical conditions. Studies have shown that, ${ }^{9}$ college students are under a lot of stress, having to deal with peer pressure, academic pressure, competition, addiction, difficult family conditions and economic conditions and thus are more prone to mental health issues. College students are also more vulnerable to suicide ${ }^{10}$ and many colleges now have realised the need for counsellors and psychological help to provide aid to students. ${ }^{9} \mathrm{~A}$ study among college students in India had shown that ${ }^{11} 18.5 \%$ suffered from depression, $24.4 \%$ suffered from anxiety and $20 \%$ suffered from stress.

This period of Covid 19 induced lockdown with special emphasis on social distancing is bound to have long term affects in all. Young adults need to learn and indulge in experiences that prepare them for a productive life. Young people mostly rely on peers for support and it is an important part of their college experience. Being robbed of this crucial support system could lead to considerable amount of stress. It has been proven in studies that prolonged amount of perceived stress particularly due to social isolation leads to impaired cognition thus impairing productivity, ${ }^{12}$ and increased vulnerability to psychological problems in the long term. A study among college students in China during the COVID 19 pandemic has shown that nearly $21.3 \%$ experienced mild anxiety while $0.9 \%$ students experienced severe anxiety. ${ }^{13}$

India has been in lockdown since March 23, 2020 and this has created economic instability and a blanket of uncertainty among all classes of people. This study hopes to measure the psychological impact caused due to the lockdown among college students during the Covid 19 pandemic.

\section{Objectives}

We wanted to measure the levels of perceived stress among college students during the complete lockdown and evaluate the financial instability during the lockdown.

\section{METHODS}

This cross-sectional study was conducted as an online survey among college students across various streams including medicine, engineering, and other undergraduate and post graduate students.

\section{Participants}

College students in the age group of 17 - 25 years were encouraged to complete the survey. 785 participants responded. 10 responses had to be discarded since they were not pursuing any college degree. A total of 775 responses were considered for the study

\section{Design and Procedure}

This study was approved by the Institutional Ethics Committee (Radians Healthcare \& Research). Participants completed an anonymous online survey by filling out a specially formulated survey form through Google forms (https://forms.gle/TRPTMVccQZjGKkcL7) that was propagated through social media. They filled out the form after submitting an informed consent and agreeing to participate in the survey. The survey was conducted between $12^{\text {th }}$ may 2020 to $31^{\text {st }}$ may 2020 , both days inclusive. No personal information was gathered in the study.

The survey form contained closed ended questions regarding their type of living before and during the lockdown. 
It also had questions regarding the use of social media and their financial situations before and during the pandemic. It included basic demographic details including the type of courses they were doing in the current academic year. A total of 19 statements including the basic socio-demographic details, their use of social media to connect to people, their worry regarding financial situation, continuation of education, future job prospects and missing out on friends and 10 statements of the perceived stress scale were included in the survey.

\section{Assessments Used}

The Perceived Stress Scale (PSS) ${ }^{14}$ is the most widely used scale to measure the perception of stress. It is an important tool to find a person's level of stress in the context of any event that could be personal or environmental. It is a 10 item liker scale with scores ranging from $0-4$, and it determines the level of perceived stress in an individual. It is suitable for group administration and hence chosen for use in this study.

\section{Data Analysis}

The data was analysed using SPSS - Statistical Package for Social Services software, (IBM Corp. released 2016. IBM SPSS statistics for windows, version 24.0. Armonk, NY: IBM Corp.). The various details pertaining to the present living conditions of college students along with demographic, financial and educational details were analysed for normal distribution. The relationship between the various variables and the perceived stress as measured by PSS is analysed using analysis of various (ANOVA) at $95 \%$ confidence level and significance < 0.05 indicating a significant correlation between them.

\section{RESULTS}

The socio demographic details along with the various information regarding financial status, use of social media and other characteristics were found to be significant to the sample size (Table 1). The total sample consisted of 295 (38.1 $\%)$ male and 480 (61.9) female students. Among the sample $230(29.7 \%)$ were living in rural area and 545 (71.3\%) were of urban origin. 303 (39.1\%) were pursuing engineering, 220 (28.4\%) were doing medicine, 173 (22.3\%) were doing postgraduate studies and 79 (10.2 \%) were doing undergraduate students. Of all the students 327 (42.2\%) were in their final year of study. 570 (73.5\%) reported that their family had a stable income and $205(26.5 \%)$ reported that their family does not have a stable income. When asked about how they had gone to college, 385 (49.7\%) reported as staying in hostel, 356(48.9\%) had been from home and 34 (4.4\%) reported that they had lived alone. During the lockdown, 742 $(95.7 \%)$ students were living with their family while 33 (4.3 $\%$ reported that they were living alone. Use of mobile phones to connect with people has increased during lockdown with $226(29.2 \%)$ reporting to spend more than $5 \mathrm{hrs}$ per day on the phone, when compared to pre-Covid conditions where 105 $(13.5 \%)$ had reported spending more than 5 hrs on the phone.

\begin{tabular}{|c|c|c|c|c|c|c|c|}
\hline Sl. No. & Factors & $\mathbf{N}$ & Mean & & SD & Stat Result & Sig \\
\hline & & & & Ag & & & \\
\hline & Below 18 & 71 & 51.41 & & 8.79 & & \\
\hline 1 & 19 to 21 & 512 & 60.72 & & 10.13 & F Patio 6827 & $\mathrm{P}<.001$ \\
\hline & $22 \&$ above & 192 & 67.10 & & 11.73 & F Katio 0.821 & SIG \\
\hline & TOTAL & 775 & 61.13 & & 10.77 & & \\
\hline 2 & & & & Genc & der & & \\
\hline & Male & 295 & 54.26 & & 9.26 & 't' Value & \\
\hline & Female & 480 & 68.66 & & 10.05 & 20.34 & $\mathrm{P}<.000$ \\
\hline & TOTAL & 775 & 61.13 & & 10.77 & & \\
\hline & & & & Place of & f Living & & \\
\hline 3 & Rural & 230 & 50.78 & & 10.34 & 't' Value & \\
\hline & Urban & 545 & 66.27 & & 10.95 & 18.72 & $\begin{array}{l}P<.000 \\
\text { SSC }\end{array}$ \\
\hline & TOTAL & 775 & 61.13 & & 10.77 & & \\
\hline & & & Family th & lat have & Steady In & & \\
\hline 4 & Yes & 570 & 51.69 & & 10.99 & 't' Value & \\
\hline & No & 205 & 62.34 & & 11.08 & 11.83 & $\begin{array}{l}\mathrm{P}<.000 \\
\text { SSC }\end{array}$ \\
\hline & TOTAL & 775 & 61.13 & & 10.77 & & \\
\hline & & & Cour & se pres & ently doin & & \\
\hline & UG & 79 & 50.30 & & 10.93 & & \\
\hline 5 & Engineering & 303 & 60.45 & & 11.59 & & \\
\hline 5 & Medicine & 220 & 52.61 & & 11.24 & F Ratio & $\begin{array}{l}\mathrm{P}<.002 \\
\mathrm{SSC}\end{array}$ \\
\hline & PG & 173 & 66.35 & & 10.77 & 8.529 & \\
\hline & TOTAL & 775 & 61.13 & & 10.77 & & \\
\hline & & & & nal year & r Student & & \\
\hline 6 & Yes & 327 & 66.40 & & 10.78 & 't' Value & \\
\hline & No & 448 & 50.93 & & 11.77 & 18.98 & $\begin{array}{l}\mathrm{P}<.000 \\
\text { SII }\end{array}$ \\
\hline & TOTAL & 775 & 61.13 & & 10.77 & & \\
\hline & & & You & go to $\mathrm{Co}$ & ollege from & & \\
\hline & Hostel & 385 & 52.24 & & 13.37 & & \\
\hline 7 & Home & 356 & 49.65 & & 11.95 & & $\mathrm{P}<.009$ \\
\hline & Live alone & 34 & 63.97 & & 12.69 & F Ratio & SIG \\
\hline & TOTAL & 775 & 61.13 & & 10.77 & & \\
\hline & & & Curr & ently st & taying with & & \\
\hline 8 & Parents & 742 & 50.02 & & 11.87 & 't' Value & \\
\hline & Alone & 33 & 59.48 & & 9.98 & 5.28 & $\begin{array}{l}\mathrm{P}<.002 \\
\mathrm{~S} / \mathrm{C}\end{array}$ \\
\hline & TOTAL & 775 & 61.13 & & 10.77 & & \\
\hline & & & Do yc & ke y & your Colleg & & \\
\hline & I Like it a lot & 360 & 49.54 & & 10.29 & & \\
\hline 9 & It is okay & 355 & 55.99 & & 10.94 & & $\mathrm{P}<.001$ \\
\hline & Do not like & 60 & 65.54 & & 11.25 & F Ratio & \\
\hline & TOTAL & 775 & 61.13 & & 10.77 & & \\
\hline & & Time sp & end Conr & lecting $\mathrm{v}$ & with peopl & ver phone & \\
\hline & Below 1 & & 347 & 48.53 & 10.88 & & \\
\hline 10 & (2 to 5$)$ & & 323 & 55.52 & 11.97 & F Ratio & $\mathrm{P}<.012$ \\
\hline & More $5 \mathrm{l}$ & & 105 & 61.88 & 10.74 & 6.347 & SIG \\
\hline & TOTA & & 775 & 61.13 & 10.77 & & \\
\hline & & Time Sp & end Conr & lecting $v$ & with friend & n real time & \\
\hline & Below 1 & & 178 & 63.90 & 10.94 & & \\
\hline 11 & (2 to 5$)$ & & 234 & 56.75 & 8.36 & & \\
\hline & More 51 & & 363 & 49.99 & 9.44 & F Ratio & $\begin{array}{l}\mathrm{P}<.000 \\
\text { CIC }\end{array}$ \\
\hline & TOTA & & 775 & 61.13 & 10.77 & 10.324 & \\
\hline & Time spe & nt durin & ig Lockd & wn Con & anecting w & people over $\mathrm{p}$ & hone \\
\hline & Below 1 & & 279 & 61.16 & 13.28 & & \\
\hline 12 & (2 to 5$)$ & & 270 & 53.31 & 12.44 & & $\mathrm{P}<.001$ \\
\hline & More $5 \mathrm{l}$ & & 226 & 47.06 & 12.50 & $\begin{array}{l}\text { F Katio } \\
0.627\end{array}$ & SIG \\
\hline & TOTA & & 775 & 61.13 & 10.77 & & \\
\hline & & me Spen & t now Co & nnectin & Ig with peo & e in real time & \\
\hline & At hom & & 512 & 50.92 & 13.08 & & \\
\hline 13 & $1-2 \mathrm{hr}$ & & 108 & 52.89 & 13.70 & & $\mathrm{P}<.287$ \\
\hline & More $2 \mathrm{l}$ & & 155 & 50.56 & 10.88 & F katio & NS \\
\hline & TOTA & & 775 & 61.13 & 10.77 & & \\
\hline & & & gerly wa & iting to & go back to & llege & \\
\hline & Very mu & & 471 & 43.55 & 12.19 & & \\
\hline 14 & Not mu & & 251 & 51.27 & 13.66 & F Ratio & $\mathrm{P}<.024$ \\
\hline & Not like to g & go back & 53 & 55.57 & 12.82 & 3.733 & SIG \\
\hline & TOTA & & 775 & 61.13 & 10.77 & & \\
\hline & & Missing & griends & or famil & ly during $t$ & lockdown & \\
\hline & Very mu & & 575 & 50.82 & 11.87 & & \\
\hline 15 & Not so $\mathrm{m}$ & luch & 173 & 51.37 & 14.71 & F Ratio & $\mathrm{P}<.001$ \\
\hline & Not at & & 27 & 56.11 & 16.80 & 6.266 & SIG \\
\hline & TOTA & & 775 & 61.13 & 10.77 & & \\
\hline & & Family & Financial & ly stabl & e during t & Lockdown & \\
\hline 16 & Stable & & 628 & 49.75 & 12.66 & & \\
\hline 16 & Worse & & 147 & 63.70 & 11.79 & 't' Value & $\mathrm{P}<.001$ \\
\hline & TOTA & & 775 & 61.13 & 10.77 & & SIG \\
\hline & & Educ & ation wil & be affe & cted by th & ovid-19 & \\
\hline & Very mu & & 384 & 58.21 & 13.18 & & \\
\hline 17 & Small eff & ects & 270 & 49.52 & 11.73 & F Ratio & \\
\hline & No differ & ence & 121 & 48.10 & 12.64 & 10.928 & $\begin{array}{l}\mathrm{P}<.000 \\
\text { CIC }\end{array}$ \\
\hline & TOTA & & 775 & 61.13 & 10.77 & & \\
\hline & Wor & ried al & out going & out afte & er the lock & $n$ is released & \\
\hline & Very muc & h so & 312 & 57.02 & 12.63 & & \\
\hline 18 & Not mucl & $\mathrm{h}$ so & 339 & 52.26 & 12.65 & F Ratio & \\
\hline & Not worr & ried & 124 & 50.25 & 13.36 & 9.555 & $\begin{array}{l}\mathrm{P}<.002 \\
\text { S }\end{array}$ \\
\hline & TOTA & & 775 & 61.13 & 10.77 & & \\
\hline & Worr & $y$ that & ob prosp & ects will & I be affecte & dueto Covid 1 & \\
\hline & Very muc & h so & 574 & 59.01 & 12.68 & & \\
\hline 19 & Not mucl & $\mathrm{h}$ so & 159 & 48.41 & 12.47 & F Ratio & \\
\hline & Not worr & ried & 42 & 40.35 & 13.75 & 5.432 & $\mathrm{P}<.005$ \\
\hline & TOTA & & 775 & 61.13 & 10.77 & & SIG \\
\hline
\end{tabular}


While 363 (46.8\%) had reported that they usually spent more than 5 hrs per week connecting with people, it has dropped to 155 (20\%) during the lockdown and 512 (66.1\%) had reported that they only connected with people at home.

The overall perceived stress (PS) as calculated from PSS, shows that 57 (7.4\%) people experienced low PS and 629 (81.2\%) people experienced moderate PS and 89 (11.5\%) people experiences high PS (table 2).

\begin{tabular}{|ccc|}
\hline & Frequency N & Percent \% \\
\hline Low Perceived stress & 57 & 7.4 \\
Moderate Perceived stress & 629 & 81.2 \\
High Perceived stress & 89 & 11.5 \\
Total & $\mathbf{7 7 5}$ & $\mathbf{1 0 0 . 0}$ \\
\hline \multicolumn{2}{|c|}{ Table 2. Total Perceived Stress } \\
\hline
\end{tabular}

When asked about their present financial situation, 628 (81\%) felt it was stable during the lockdown and 147 (19\%) felt that it was getting worse. With regard to worry regarding the impact of lockdown on their education, 384 (49.5\%) felt that it has been affected very much, while 270 (34.8\%) reported being little worried and $121(15.6 \%)$ felt that there was no effect. 574 (74.1\%) college students were worried that their job prospects would be affected by Covid 19, while only $42(5.4 \%)$ students believed that there will be no affect and $159(20.5 \%)$ believed that there will be some effect in job prospects due to COVID 19. 312 (40.3\%) students were very worried and $339(43.7 \%)$ were somewhat worried about going out after lockdown and only 124 (16\%) of student reported that they were not worried about going out after lockdown.

Analysis of variance for place of residence before and during the lockdown shows that it has a low amount of influence on the amount of perceived stress, $F(5,769)=2.13$, sig $=0.06$, and students who were living at home prior and during the lockdown experienced the lowest amount of stress as indicated with a low mean score $\mathrm{M}=49.61$ and students who were living alone during the lockdown irrespective of whether they had lived in hostel or with parents prior to lockdown, experienced the highest amount of perceived stress at mean score of $\mathrm{M}=52$ and 55 respectively. The amount of time spent connecting with people over phone and in real time during the period of lockdown has a considerable influence in the amount of perceived stress, $F(8,766)=3.66$, sig $=0.00$ and students who are were spending less than $1 \mathrm{hrs}$ per day over the phone and were spending more than 2 hrs per day in the company of friends, experienced the lowest amount perceived stress as indicated by low mean score $M=61.5$. Student who were spending more than $5 \mathrm{hrs}$ per day over the phone and who did not get to spend time with friends in real time experience more amount of perceived stress with mean score $M=42.5$. The type of degree, the students were pursuing and their worry regarding the effect the lockdown was having on their education had a significant influence on the level of perceived stress, $\mathrm{F}(11,763)=2.62$, sig $=0.03$, with students pursuing medicine and postgraduates experiencing high perceived stress due to their worry regarding the education being affected at mean score $M=55.03$ and 51.73 respectively and engineering students showing least amount of stress regarding their effect it has on their education with mean score M 46.82. Students in their final year of study and who worried about the job prospects being affected by COVID were found to have increased amount of perceived stress, $\mathrm{F}(5,500)=2.47$, sig=0.032 (table 3 , figure 1 , table 4 )

Influence of students who were in their final year of study and their worry regarding job prospects being affected by Covid 19 with respect to Total Perceived Stress (table 3, figure 1, table 4)

\begin{tabular}{|c|c|c|c|c|c|c|c|c|}
\hline 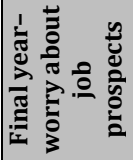 & z & 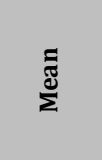 & 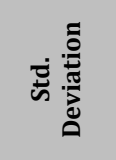 & 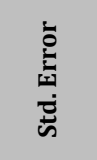 & 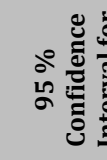 & 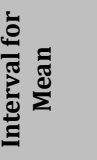 & $\underset{\Xi}{\Xi}$ & 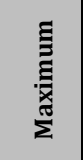 \\
\hline & & & & & $\begin{array}{l}\text { Lower } \\
\text { Bound }\end{array}$ & $\begin{array}{l}\text { Upper } \\
\text { Bound }\end{array}$ & & \\
\hline $\begin{array}{c}1 \text { (Yes-Very } \\
\text { much) }\end{array}$ & 155 & 52.6935 & 12.03194 & .96643 & 50.7844 & 54.6027 & 30.00 & 100.00 \\
\hline $\begin{array}{c}2 \text { (Yes-Not } \\
\text { much) }\end{array}$ & 37 & 49.3919 & 14.19611 & 2.33383 & 44.6587 & 54.1251 & 17.50 & 87.50 \\
\hline $\begin{array}{c}3 \text { (Yes- No } \\
\text { Worry) }\end{array}$ & 11 & 45.6818 & 11.01652 & 3.32160 & 38.2808 & 53.0828 & 32.50 & 65.00 \\
\hline $\begin{array}{c}4 \text { (No-Very } \\
\text { much) }\end{array}$ & 233 & 51.4163 & 12.45814 & .81616 & 49.8083 & 53.0243 & 20.00 & 87.50 \\
\hline $\begin{array}{c}5 \text { (No-Not } \\
\text { much) }\end{array}$ & 58 & 46.9397 & 12.68757 & 1.66596 & 43.6036 & 50.2757 & 20.00 & 77.50 \\
\hline $\begin{array}{l}6 \text { (No-No } \\
\text { Worry) }\end{array}$ & 12 & 48.5417 & 12.49811 & 3.60789 & 40.6007 & 56.4826 & 27.50 & 65.00 \\
\hline Total & 506 & 50.9536 & 12.55354 & .55807 & 49.8571 & 52.0500 & 17.50 & 100.00 \\
\hline \multicolumn{9}{|c|}{ SDIM 1 Total Perceived Stress } \\
\hline
\end{tabular}

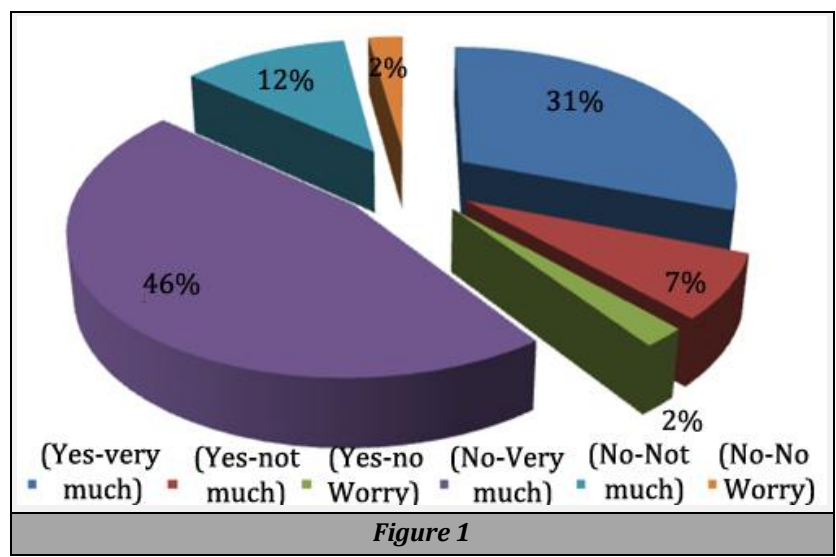

\begin{tabular}{|c|c|c|c|c|c|}
\hline & $\begin{array}{c}\text { Sum of } \\
\text { Squares }\end{array}$ & DF & $\begin{array}{c}\text { Mean } \\
\text { Square }\end{array}$ & $\mathbf{F}$ & Sig. \\
\hline Between Groups & 1919.375 & 5 & 383.875 & \multirow{3}{*}{2.471} & \multirow{3}{*}{.032} \\
\hline Within Groups & 77664.283 & 500 & 155.329 & & \\
\hline Total & 79583.659 & 505 & & & \\
\hline \multicolumn{6}{|c|}{ SDIM1 Total Perceived Stress } \\
\hline \multicolumn{6}{|c|}{$\begin{array}{l}\text { Table 4. Influence of Perceived Stress in Relation to Final Year } \\
\text { of Study and Worry Regarding Job Prospects }\end{array}$} \\
\hline
\end{tabular}

\section{DISCUSSION}

This study among college students indicates that $11.5 \%$ of students were experiencing high stress and $81.2 \%$ experienced moderate amount of stress and only $7.4 \%$ reported mild stress levels. The level of stress perceived by the college students in this study were found to be significantly influenced by the changes in social experiences as indicated by the increase in stress with relation to the increased use of mobile phones and low level of social interaction.

Worry regarding their education and job prospects being affected had a significant influence on the level of perceived stress. These stressors are bound to be persistent due to the current situation caused by the pandemic and a return to a pre 
pandemic era is not possible in the near future. Changes caused in the context of financial security, education, job prospects and concerns about health will persist for many months and could have detrimental effects in the mental health of college students.

The various stakeholders involved in the welfare of students need to devise programmes to protect the welfare of students. This study indicates that being with family during this lockdown might be a good protective factor and $74.2 \%$ of them reported that they missed family and friends during this lockdown. Students need peer support and guidance to overcome stress in relation to academic related issues. Previous studies have shown that $10-20 \%$ of college students experienced psychological problems like anxiety and depression ${ }^{15}$ and the prolonged stress induced by COVID 19, could result in worsening of the mental state of the students.

The authors understand that this being an online survey, only students with access to smart phones and with access to internet were able to participate and that due to the lockdown it was difficult to limit data to a particular college or city. Students in a college usually belong to different cities or states and hence this sample is random. However, similar studies targeting particular colleges or universities could be done to assess their mental health and appropriate psychosocial help could be made available to them.

\section{CONCLUSIONS}

College students are more vulnerable to psychological problems due to the highly stressful environment caused by the pandemic situation. This study shows that college students were experiencing stress at various levels and the perceived stress was significantly influenced by their stay with family during the period of lockdown.

Perceived stress was significantly influenced by the lack of social interaction and worry regarding education and job prospects. There could be other factors influencing the mental state of college students that were not included in the study. Further intensive studies are required to find the other factors that might have a psychological impact in college students. As of 2018-2019,16 India has about 36.4 to 37.4 million college students.

They are a valuable resource to the nation and their wellbeing should be prioritised and it should be addressed at the earliest to prevent instances of mental health problems among them as suggested by studies ${ }^{17}$ by providing continuous online support in the form of classes and support by the college staff and counselling and career guidance services.

Financial or Other Competing Interests: None.

\section{REFERENCES}

[1] World Health Organization. Mental health and psychosocial considerations during COVID-19 outbreak. World Health Organization 2020:1-6. https://www.who.int/docs/default- source/coronaviruse/mental-healthconsiderations.pdf?sfvrsn=6d3578af_10

[2] Huremović D. Psychiatry of pandemics. Cham: Springer International Publishing 2019. http://link.springer.com/10.1007/978-3-030-15346-5

[3] Auerbach RP, Alonso J, Axinn WG, et al. Mental disorders among college students in the World Health Organization World Mental Health Surveys. Psychol Med 2016;46(14):2955-70.

[4] Brooks SK, Webster RK, Smith LE, et al. The psychological impact of quarantine and how to reduce it: rapid review of the evidence. The Lancet 2020;395(10227):912-20.

[5] Reynolds DL, Garay JR, Deamond SL, et al. Understanding, compliance and psychological impact of the SARS quarantine experience. Epidemiol Infect 2008;136(7):997-1007.

[6] Troyer EA, Kohn JN, Hong S. Are we facing a crashing wave of neuropsychiatric sequelae of COVID-19? Neuropsychiatric symptoms and potential immunologic mechanisms. Brain Behav Immun 2020;87:34-9.

[7] Behere SP, Yadav R, Behere PB. A comparative study of stress among students of medicine, engineering, and nursing. Indian J Psychol Med 2011;33(2):145-8.

[8] Baghurst T, Kelley BC. An examination of stress in college students over the course of a semester. Health Promot Pract 2014;15(3):438-47.

[9] Kitzrow MA. The Mental health needs of today's college students: challenges and recommendations. NASPA J 2003;41(1):165-79.

[10] Mowbray CT, Megivern D, Mandiberg JM, et al. Campus mental health services: recommendations for change. Am J Orthopsychiatry 2006;76(2):226-37.

[11] Sahoo S, Khess CRJ. Prevalence of depression, anxiety, and stress among young male adults in India: a dimensional and categorical diagnoses-based study. J Nerv Ment Dis 2010;198(12):901-4

[12] Cacioppo JT, Hawkley LC. Perceived social isolation and cognition. Trends Cogn Sci 2009;13(10):447-54.

[13] Cao W, Fang Z, Hou G, et al. The psychological impact of the COVID-19 epidemic on college students in China. Psychiatry Res 2020;287:112934.

[14] Cohen S. Percieved Stress Scale. Mind Garden Inc 1994. https://www.sprc.org/system/files/private/eventtraining/Penn College - Perceived Stress Scale.pdf

[15] Kumaraswamy N. Academic stress, anxiety and depression among college students-a brief review. Int Rev Soc Sci Humanit 2013;5(1):135-43.

[16] Nanda PK. India's higher education student population grows by 8 lakh: HRD ministry. https://www.livemint.com/education/news/india-shigher-education-student-population-grows-by-8-lakhhrd-ministry-1569081600712.html

[17] Zhai Y, Du X. Addressing collegiate mental health amid COVID-19 pandemic. Psychiatry Res 2020;288:113003. 